\title{
Circulating Adipokine Levels in Non-diabetic Subjects with High Normal Blood Pressure
}

\author{
AF Rubio-Guerra ${ }^{1,2}$, H Vargas-Robles ${ }^{3}$, MB Durán-Salgado $^{1,2}$, JJ Lozano-Nuevo $^{1,2}$, \\ G Vargas-Ayala ${ }^{1,2}$, BA Escalante-Acosta ${ }^{4}$
}

\begin{abstract}
Objective: This study aimed to evaluate the levels of the adipokines, resistin and adiponectin in normotensive and high normal blood pressure patients.

Methods: Circulating levels of the adipokines, resistin and adiponectin were measured by enzyme-linked immunosorbent assay (ELISA; R\&D Systems, Minneapolis) in 20 high normal blood pressure patients and in 20 age-matched normotensive non-diabetic subjects. Statistical analysis was performed with analysis of variance (ANOVA).

Results: The control group showed non-significantly decreased levels of resistin when compared with patients with high normal blood pressure [systolic 130-139 $\mathrm{mmHg}$; diastolic 85-89 $\mathrm{mmHg}$ ] (12.25 vs $14.38 \mathrm{pg} / \mathrm{mL}, \mathrm{p}=0.40)$. There were significantly higher levels of adiponectin in the control group when compared with high normal blood pressure patients $(11.3$ vs $7.51 \mu \mathrm{g} / \mathrm{mL}, \mathrm{p}=0.028)$.

Conclusion: High normal blood pressure patients have increased levels of resistin and lower values of adiponectin when compared with age-matched non-diabetic normotensive subjects. This may explain why those patients showed more progression to hypertension, atherosclerosis and cardiovascular risk than normotensive subjects.
\end{abstract}

Keywords: Adiponectin, high normal blood pressure, inflammation, resistin

\section{Niveles circulantes de adipoquinas en sujetos no diabéticos con presión arterial nor- mal-alta \\ AF Rubio-Guerra ${ }^{1,2}$, H Vargas-Robles ${ }^{3}$, MB Durán-Salgado ${ }^{1,2}$, JJ Lozano-Nuevo ${ }^{1,2}$, G Vargas-Ayala ${ }^{1,2}$, BA Escalante-Acosta ${ }^{4}$}

\begin{abstract}
RESUMEN
Objetivos: Este estudio persigue evaluar los niveles de adipoquina, resistina y adiponectina en pacientes normotensos y prehipertensos.

Métodos: Los niveles circulantes de adipoquinas, resistina y adiponectina fueron medidos mediante ensayo por inmunoadsorción ligado a enzimas (ELISA; R\&D Systems, Minneapolis) en 20 pacientes con presión arterial normalmente alta y en 20 sujetos no diabéticos normotensos pareados por edad. El análisis estadístico se realizó con el análisis de varianza (ANOVA).

Resultados: El grupo de control mostró niveles de resistina disminuidos de manera no significativa en comparación con los pacientes de presión arterial normal-alta [sistólica 130-139 mmHg; diastólica 85-89 $\mathrm{mmHg}](12.25 \mathrm{vs} .14 .38 \mathrm{pg} / \mathrm{mL}, \mathrm{p}=0.40)$. Habia niveles de adiponectina significativamente más altos en el grupo control en comparación con los pacientes de presión arterial normal-alta (11.3 vs. $7.51 \mu \mathrm{g} / \mathrm{mL}, \mathrm{p}=0.028)$.

Conclusión: Los pacientes con presión arterial normal-alta presentan un aumento de los niveles del resistina y valores bajos de adiponectina en comparación con los sujetos normotensos no diabéticos pareados por edad. Esto puede explicar por qué esos pacientes mostraron mayor progresión a la hipertensión, la aterosclerosis, y riesgo cardiovascular que los sujetos normotensos.
\end{abstract}

From: ${ }^{1}$ Unidad de Investigación Clínico-Metabólica, Hospital General de Ticomán SS DF, México, ${ }^{2}$ Mexican Group for Basic and Clinical Research in Internal Medicine, AC México, ${ }^{3}$ Departamento de Biomedicina Molecular, Centro de Investigación y de Estudios Avanzados del Instituto Politécnico Nacional, México and ${ }^{4}$ Centro de Investigación y de Estudios Superiores, Monterrey, México.

Correspondence: Dr AF Rubio-Guerra, Plan de San Luis S/N Esq Bandera, Col Ticomán, México DF CP 07330. Fax (52 555) 75439 39; e-mail: clinhta@hotmail.com 
Palabras claves: Adiponectina, inflamación, resistina, prehipertensión

\section{West Indian Med J 2016; 65 (2): 261}

\section{INTRODUCTION}

Traditionally, adipose tissue has been considered as a fat depot. However, it is now recognized that adipocytes secrete several bioactive factors known as adipokines, some of which are shown in Table 1 (1).

Table 1: Secretory products of adipose tissue

\begin{tabular}{ll}
\hline Inflammatory actions & $\begin{array}{l}\text { Tumour necrosis factor } \alpha \text {, interleukins }(1 \beta, 6), \\
\text { transforming growth factor } \beta-1, \text { resistin, omentin } \\
\text { (anti-inflammatory), adiponectin (anti-inflammatory) }\end{array}$ \\
Metabolic actions & $\begin{array}{l}\text { Adiponectin, resistin, leptin, visfatin, omentin, } \\
\text { dipeptidyl peptidase-4, apelin }\end{array}$ \\
Prothrombotic & Plasminogen activator inhibitor-1 \\
Vasomotor effects & Angiotensin, prorenin \\
\hline
\end{tabular}

Adipokines contribute to adipocyte metabolism and function; they modulate and regulate different biological processes such as insulin resistance, inflammation, and the risk of developing metabolic and cardiovascular complications. When adipose tissue dysfunction has developed, adipokine secretion is significantly changed toward a diabetogenic, proinflammatory and atherogenic pattern (1).

Adiponectin and resistin modulate insulin action; adiponectin improves insulin sensitivity and has anti-inflammatory properties, whereas resistin is associated with insulin resistance and metabolic syndrome; this adipokine impairs endothelial function and has proinflammatory effects (2).

Hypoadiponectinaemia has been reported as a risk factor for the development of cardiovascular disease (3), and hyperrestinaemia is associated with pathways that lead to atherosclerosis and cardiovascular disease (4).

Borderline hypertension is defined by the Mexican regulations as the presence of systolic blood pressure (BP) between $130 \mathrm{mmHg}$ and $139 \mathrm{mmHg}$ and $/$ or a diastolic BP between 85 $\mathrm{mmHg}$ and $89 \mathrm{mmHg}(5)$. These values of blood pressure are referred to as high normal blood pressure (HNBP), by the 2013 European Society for Hypertension/European Society for Cardiology Guidelines for the Management of Arterial Hypertension [ESG] (6).

Cardiovascular risk increases at systolic BP of 130 and diastolic BP of $85 \mathrm{mmHg}$. In fact, individuals with BP values in the range of HNBP, enrolled in the Strong Heart Study, showed a two-fold higher prevalence of left ventricular hypertrophy than their normotensive counterparts (7). Although the associated cardiovascular risk in those patients is unclear, evidence suggests that people with BP in the HNBP range may be at increased cardiovascular risk. Those subjects also show increased carotid artery intimal-media thickness and arterial stiffness (8).
The aim of this study was to evaluate circulating levels of theadipokines, adiponectin and resistin in non-diabetic patients with HNBP.

\section{SUBJECTS AND METHODS}

The study comprised 20 non-diabetic patients with HNBP (as defined by 2013 ESG) and 20 age-matched normotensive controls.

Venous samples were collected in the morning after a 12-hour overnight fast. Circulating levels of adiponectin and resistin were measured in duplicate using commercially available enzyme-linked immunosorbent assay (ELISA) kits (R\&D Systems, Minneapolis, MN, USA), following manufacturer's recommendations. Enzyme-linked immunosorbent assays were performed by personnel blinded to the study. Intra-assay coefficient of variability $(\mathrm{CV})$ for adiponectin was $3.4 \%$ and inter-assay $\mathrm{CV}$ was $5.8 \%$, whereas intra-assay CV for resistin was $5.5 \%$ and inter-assay CV was $9.2 \%$.

Patients with any of the following diagnoses were excluded from the study: diabetes mellitus [according to the American Diabetes Association criteria] (9); heart, hepatic, or renal failure; evidence of valvular heart disease, heart block or cardiac arrhythmia, acute coronary syndrome or cerebrovascular disease six months before the study's initiation; autoimmune disease; pregnancy; urinary tract infection; fever, or a history of alcohol abuse and/or psychotropic drugs.

The study was conducted with the approval of the Research and Medical Ethics Committee of our hospital, in accordance with the Declaration of Helsinki. Participants gave written informed consent before their inclusion in the study protocol. Statistical analysis was formed with analysis of variance test. $p<0.05$ was considered as statistically significant.

\section{RESULTS}

The basal characteristics of the patients and controls are shown in Table 2. The HNBP group showed a non-significant increase in the levels of resistin when compared with controls (14.38 vs $12.25 \mathrm{pg} / \mathrm{mL}, p=0.40)$. There were significantly lower levels of adiponectin in HNBP (7.51 vs $11.3 \mu \mathrm{g} / \mathrm{mL}$, $p=0.028)$, when compared with the age-matched normotensive controls (Figure).

Table 2: Basal characteristic of the subjects

\begin{tabular}{lllc}
\hline & High normal blood pressure & Normotensive & $p$ \\
\hline Age (years) & $58 \pm 10$ & $57 \pm 10$ & $\mathrm{~ns}$ \\
Gender (M/F) & $7 / 13$ & $6 / 14$ & $\mathrm{~ns}$ \\
Glycaemia (mg/dL) & $100 \pm 11$ & $100 \pm 10$ & $\mathrm{~ns}$ \\
Blood pressure (mmHg) & $136 / 86$ & $122 / 76$ & $<0.01$ \\
LDL (mg/dL) & $128 \pm 24$ & $127 \pm 28$ & $\mathrm{~ns}$ \\
Body mass index & $29.5 \pm 7$ & $29.8 \pm 6$ & $\mathrm{~ns}$ \\
\hline
\end{tabular}

LDL: low-density lipoprotein 


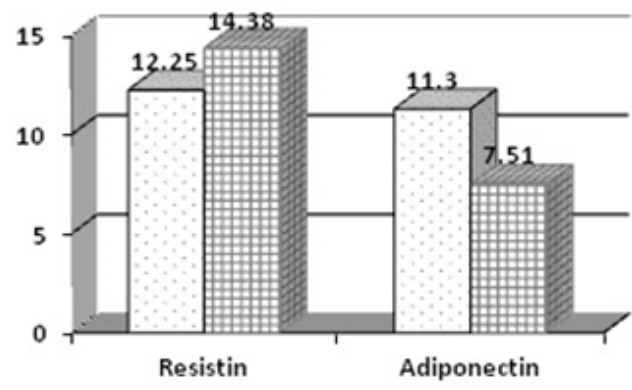

口Control घhigh Normal Blood Pressure

Figure: Adipokine levels in patients and controls.

\section{DISCUSSION}

In this study, HNBP non-diabetic patients had higher circulating levels of resistin and lower adiponectin than normotensive controls. The methodology was strengthened by duplicate determinations of adipokines, so intra-individual variation was taken into account, and the exclusion of diabetic patients, since diabetes mellitus may modify adipokine levels with potential interference in the analysis of the results (10).

Both hypoadiponectinaemia and hyperresistinaemia are associated with the coexistence of hypertension and Type 2 diabetes (2). Kawamoto et al found that high molecular weight adiponectin levels correlated with blood pressure in men, but not women (11); however, in their study, resistin levels were not assessed. Patients with BP values in the range of HNBP have a higher risk to develop hypertension than normotensive patients (12). But whether the progression from HNBP to hypertension is dependent (solely or in part) on adipokine levels requires further investigation.

Papadopoulos et al (13) found that patients with prehypertension had significantly higher resistin plasma levels and significantly lower adiponectin plasma levels than healthy normotensive subjects, whereas in our study, although adiponectin levels were significantly lower in HNBP, no difference was found in resistin levels between groups. It is important to note that the patients in the present study had a greater body mass index than those from the study of Papadopoulos.

Besides a possible role in the progression from HNBP to hypertension, the results may have prognostic implications. Data from the Framingham study indicated that BP values in the range of HNBP are associated with a two-fold increase in the risk of cardiovascular disease when compared with normotensive patients (14). Patients with BP values in that range also show increased carotid artery intimal-media thickness (9). Indeed hypoadiponectinaemia and hyperresistinaemia are associated with a higher risk for the development of cardiovascular disease, and both resistin and the adiponectin/resistin index (which includes information about the circulating levels of both adipokines), correlate with the carotid intima-media thickness (4). Our findings may explain, at least in part, the pathways that lead to the increased cardiovascular risk in patients with HNBP.

In conclusion, patients with high normal blood pressure have lower values of adiponectin, and non-significantly higher levels of resistin than non-diabetic normotensive subjects. This may explain why those patients with HNBP show more atherosclerosis and cardiovascular risk than normotensive subjects.

\section{REFERENCES}

1. Blüher M. Adipokines - removing road blocks to obesity and diabetes therapy. Mol Metab 2014; 3: 230-40.

2. Li ZY, Wang P, Miao CY. Adipokines in inflammation, insulin resistance and cardiovascular disease. Clin Exp Pharmacol Physiol 2011; 38: 888-96.

3. Behre CJ. Adiponectin, obesity and atherosclerosis. Scand J Clin Lab Invest 2007; 67: 449-58.

4. Rubio-Guerra AF, Cabrera-Miranda JL, Vargas-Robles H, Maceda-Ser rano A, Lozano-Nuevo JJ, Escalante-Acosta BA. Correlation between levels of circulating adipokines and adiponectin/resistin index with carotid intima-media thickness in hypertensive type 2 diabetic patients. Cardiology 2013; 125: 150-3.

5. Diario Oficial de la Federación. Modificación a la Norma Oficial Mexicana NOM-030-SSA2-1999, para la prevención, tratamiento y control de la hipertensión arterial, para quedar como Norma Oficial Mexicana NOM-030-SSA2-2009, para la prevención, detección, diagnóstico, tratamiento y control de la hipertensión arterial sistémica. Ciudad de México: Diario Oficial de la Federación; 2009 Nov 24. Available from: http://dof.gob.mx/nota_detalle.php?codigo $=5144642 \&$ fecha $=31 / 05$ / 2010

6. Task Force for the Management of Arterial Hypertension of the European Society of Hypertension; Task Force for the Management of Arterial Hypertension of the European Society of Cardiology. 2013 ESH/ESC Guidelines for the Management of Arterial Hypertension. Blood Press 2013; 22: 1930-278.

7. Drukteinis JS, Roman MJ, Fabsitz RR, Lee ET, Best LG, Russell M et al. Cardiac and systemic hemodynamic characteristics of hypertension and prehypertension in adolescents and young adults: the Strong Heart Study. Circulation 2007; 115: 221-7.

8. Urbina EM, Khoury PR, McCoy C, Daniels SR, Kimball TR, Dolan LM. Cardiac and vascular consequences of pre-hypertension in youth. J Clin Hypertens (Greenwich) 2011; 13: 332-42.

9. American Diabetes Association. Standards of medical care in diabetes - 2012. Diabetes Care 2012; 31: S11-63.

10. Jee SH, Ahn CW, Park JS, Park CG, Kim HS, Lee SH et al. Serum adiponectin and type 2 diabetes: a 6 -year follow-up cohort study. Diabetes Metab J 2013; 37: 252-61.

11. Kawamoto R, Tabara Y, Kohara K, Abe M, Kusunoki T, Miki T. Association of serum high molecular weight adiponectin and blood pressure among non-diabetic community-dwelling men. Clin Exp Hypertens 2011; 33: 336-44.

12. Zheng L, Sun Z, Zhang X, Xu C, Li J, Hu D et al. Predictors of progresgression from prehypertension to hypertension among rural Chinese adults: results from Liaoning Province. Eur J Cardiovasc Prev Rehabil 2010; 17: 217-22.

13. Papadopoulos DP, Makris TK, Krespi PG, Poulakou M, Stavroulakis G, Hatzizacharias AN et al. Adiponectin and resistin plasma levels in healthy individuals with prehypertension. J Clin Hypertens (Greenwich) 2005; 7: 729-33.

14. Chobanian AV, Bakris GL, Black HR, Cushman WC, Green LA, Izzo JL Jr et al. Seventh report of the Joint National Committee on Prevention, Detection, Evaluation, and Treatment of High Blood Pressure. Hypertension 2003; 42: 1206-52. 